\title{
Puniceicoccus vermicola gen. nov., sp. nov., a novel marine bacterium, and description of Puniceicoccaceae fam. nov., Puniceicoccales ord. nov., Opitutaceae fam. nov., Opitutales ord. nov. and Opitutae classis nov. in the phylum 'Verrucomicrobia'
}

Correspondence Jang-Cheon Cho chojc@inha.ac.kr

\author{
Yoe-Jin Choo, Kiyoung Lee, Jaeho Song and Jang-Cheon Cho \\ Division of Biology and Ocean Sciences, Inha University, Yonghyun-Dong, Incheon 402-751, \\ Republic of Korea
}

\begin{abstract}
A Gram-negative, chemoheterotrophic, facultatively anaerobic coccus, designated IMCC $1545^{\top}$, was isolated from the digestive tract of a marine clamworm, Periserrula leucophryna, inhabiting a tidal flat of the Yellow Sea. Cells of strain IMCC $1545^{\top}$ are non-motile, dividing by binary fission. The predominant fatty acids are anteiso- $C_{15: 0}$ and $C_{18: 0}$. The respiratory quinone is menaquinone-7 and the DNA G $+\mathrm{C}$ content is $\mathbf{5 2 . 1}$ mol\%. Phylogenetic analyses based on 16S rRNA gene sequences using three treeing algorithms revealed that the strain formed a novel genus-level lineage within the phylum 'Verrucomicrobia'. The most closely related named organisms to strain IMCC $1545^{\top}$ are 'Fucophilus fucoidanolyticus' SI-1234 (86.5\% 16S rRNA gene sequence similarity), Alterococcus agarolyticus $\mathrm{ADT}^{\top}$ (81.8\%) and Opitutus terrae PB90-1 ${ }^{\top}$ (80.3\%), which belong to subdivision 4 of the 'Verrucomicrobia'. Subdivision 4 of the 'Verrucomicrobia' (here named Opitutae classis nov.) was divided into two clades, a clade containing strain IMCC $1545^{\top}$ and a clade containing Opitutus terrae. From the taxonomic data obtained in this study, it is proposed that the new marine isolate be placed into a novel genus and species named Puniceicoccus vermicola gen. nov., sp. nov. (the type strain of Puniceicoccus vermicola is IMCC $1545^{\top}=$ KCCM $42343^{\top}=$ NBRC $101964^{\top}$ ) within Puniceicoccaceae fam. nov and Puniceicoccales ord. nov in the class Opitutae. The family Opitutaceae fam. nov. and order Opitutales ord. nov. are also formally proposed.
\end{abstract}

Although members of the phylum 'Verrucomicrobia' have shown to be very diverse in cultivation-independent surveys (Freitag \& Prosser, 2003; Haukka et al., 2005; Hugenholtz et al., 1998; O'Farrell \& Janssen, 1999), only a few members of the phylum have yet been cultivated (Chin et al., 2001; Derrien et al., 2004; Hedlund et al., 1997; Hugenholtz et al., 1998; Sangwan et al., 2004; Schlesner, 1987; Ward-Rainey et al., 1995). The phylum 'Verrucomicrobia' has been divided historically into five subdivisions, V1 to V5, based on $16 \mathrm{~S}$ rRNA gene sequences (Hugenholtz et al., 1998). In the second edition of Bergey's Manual of Systematic Bacteriology (Garrity et al., 2003), however, three subdivisions are included at the rank of family: the families Verrucomicrobiaceae (subdivision 1), 'Xiphinematobacteriaceae' (subdivision 2) and 'Opitutaceae' (subdivision 4). Subdivision 1 includes the freshwater species Verrucomicrobium spinosum

The GenBank/EMBL/DDBJ accession number for the 16S rRNA gene sequence of strain IMCC $1545^{\top}$ is D0539046.
(Schlesner, 1987), four freshwater species of the genus Prosthecobacter (Hedlund et al., 1996, 1997) and the humanintestinal species Akkermansia muciniphila (Derrien et al., 2004). Subdivision 2 contains only one cultured species, the recently identified 'Chthoniobacter flavus' (Sangwan et al., 2004). There are three identified species in subdivision 4 , the soil-borne species Opitutus terrae (Chin et al., 1999, 2001; Janssen et al., 1997), Alterococcus agarolyticus (Shieh \& Jean, 1998), isolated from a hot spring and originally misclassified within the class Gammaproteobacteria, and 'Fucophilus fucoidanolyticus', isolated from a sea cucumber (Sakai et al., 2003).

Here we report the characterization of a verrucomicrobial isolate cultured from the digestive tract of a marine clamworm. Taxonomic analyses indicated that this marine clamworm-associated isolate is distantly related to members of subdivision 4 of the phylum 'Verrucomicrobia' and represents a novel genus and species within subdivision 4 . In addition, to clarify the taxonomic outline of subdivision 4 of 
the phylum 'Verrucomicrobia', we formally propose Opitutae classis nov., which is composed of two novel orders, Puniceicoccales ord. nov., containing Puniceicoccaceae fam. nov., and Opitutales ord. nov., containing Opitutaceae fam. nov.

Benthic marine worms of the species Periserrula leucophryna (family Nereididae), a polychaete species endemic to the west coast of Korea, were collected in July 2005 from a depth of 1-2 $\mathrm{m}$ from tidal flat sediments on Donggum island $\left(37^{\circ}\right.$ $35^{\prime} 34.1^{\prime \prime} \mathrm{N} 126^{\circ} 31^{\prime} 7.5^{\prime \prime} \mathrm{E}$ ). The marine worms were washed three times with sterile seawater and dissected under an Olympus SZH10 stereoscopic microscope. Entire invertebrate homogenates, digestive tract tissue homogenates and soil-like aggregates from within the digestive tract were used for isolating marine invertebrate-associated micro-organisms. One hundred microlitre aliquots of tissue homogenate were spread onto marine 2216 agar (MA; Difco) and the agar plates were incubated aerobically at $20^{\circ} \mathrm{C}$ for 5,14 or 30 days. A strain, designated strain $\mathrm{IMCC} 1545^{\mathrm{T}}$, was initially isolated from a digestive tract tissue homogenate after incubation for 14 days. The strain was purified as single colonies on $\mathrm{MA}$ at $30^{\circ} \mathrm{C}$ and was stored as $10 \%(\mathrm{v} / \mathrm{v})$ glycerol suspensions at $-80^{\circ} \mathrm{C}$. Unless otherwise indicated, cultures of the strain were grown routinely on $\mathrm{MA}$ at $30^{\circ} \mathrm{C}$.

Phenotypic characterizations were performed as described in previous studies (Cho \& Giovannoni, 2003; Smibert \& Krieg, 1994) using MA as the basal medium at $30^{\circ} \mathrm{C}$, unless otherwise noted. Cell morphology was examined by scanning electron microscopy (JSM 5410LV; JEOL), energy-filtering transmission electron microscopy (LIBLA120; Carl Zeiss) and phase-contrast microscopy (Nikon 80i; Nikon). Anaerobic growth was tested on MA at $30^{\circ} \mathrm{C}$ using both the MGC anaerobic system and AnaeroPACK.Anaero (Mitsubishi Gas Chemical Company). Biochemical tests were carried out on API 20NE and API ZYM (bioMérieux) according to the manufacturer's instructions with artificial seawater $\left(\mathrm{l}^{-1}: 25.0 \mathrm{~g} \mathrm{NaCl}, 1.0 \mathrm{~g} \mathrm{MgCl}_{2} .6 \mathrm{H}_{2} \mathrm{O}, 5.0 \mathrm{~g}\right.$ $\mathrm{MgSO}_{4} .7 \mathrm{H}_{2} \mathrm{O}, 0.7 \mathrm{~g} \mathrm{KCl}, 0.15 \mathrm{~g} \mathrm{CaCl}_{2} .2 \mathrm{H}_{2} \mathrm{O}, 0.5 \mathrm{~g} \mathrm{NH}_{4} \mathrm{Cl}$, $0.1 \mathrm{~g} \mathrm{KBr}, 0.27 \mathrm{~g} \mathrm{KH}_{2} \mathrm{PO}_{4}, 0.04 \mathrm{~g} \mathrm{SrCl}_{2} .6 \mathrm{H}_{2} \mathrm{O}, 0.025 \mathrm{~g}$ $\mathrm{H}_{3} \mathrm{BO}_{3}$ ). Pigments of strain IMCC $1545^{\mathrm{T}}$ were extracted with acetone/methanol $(1: 1, \mathrm{v} / \mathrm{v})$ and absorption spectra were determined using a scanning UV/visible spectrophotometer (Optizen 2120UV; Mechasis). The ability of the strain to oxidize 95 different carbon sources was determined using Biolog GN2 microplates with artificial seawater. The following antibiotics were tested: ampicillin $(10 \mu \mathrm{g})$, chloramphenicol $(25 \mu \mathrm{g})$, erythromycin $(15 \mu \mathrm{g})$, gentamicin $(10 \mu \mathrm{g})$, kanamycin $(30 \mu \mathrm{g})$, penicillin $\mathrm{G}(10 \mu \mathrm{g})$, rifampicin $(50 \mu \mathrm{g})$, streptomycin $(10 \mu \mathrm{g})$, tetracycline $(30 \mu \mathrm{g})$ and vancomycin $(30 \mu \mathrm{g})$.

Cells of strain IMCC $1545^{\mathrm{T}}$ are cocci, $0.6-1.0 \mu \mathrm{m}$ in diameter (Fig. 1). No flagella were found. Carotenoid pigments with absorbance spectrum peaks at 320 and $480 \mathrm{~nm}$ were found; the latter peak was minutely separated into three peaks at 450, 480 and $504 \mathrm{~nm}$. Anaerobic cultures grew much slower than aerobic cultures. In the API $20 \mathrm{NE}$ test, tests for nitrate

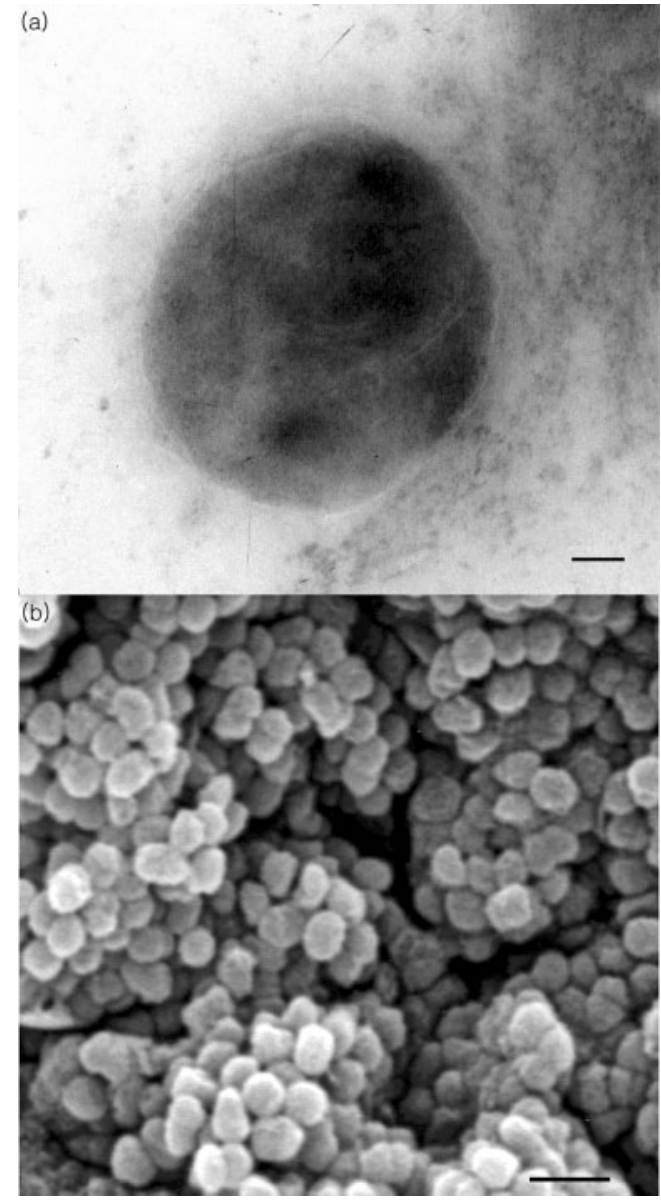

Fig. 1. Electron micrographs of strain $I M C C 1545^{\top}$. (a) Transmission electron micrograph of a negatively stained single cell. Bar, $0.1 \mu \mathrm{m}$. (b) Scanning electron micrograph of cell colonies. Bar, $1 \mu \mathrm{m}$.

reduction, indole production, glucose fermentation, arginine dihydrolase, urease, aesculin hydrolysis, gelatinase and PNPG ( $\beta$-galactosidase) were negative. In the API ZYM test, positive reactions were observed for alkaline phosphatase, esterase (C4), esterase lipase (C8), acid phosphatase and naphthol-AS-BI-phosphohydrolase and negative reactions were observed for lipase (C14), leucine, valine and cystine arylamidases, trypsin, $\alpha$-chymotrypsin, $\alpha$-galactosidase, $\beta$ galactosidase, $\beta$-glucuronidase, $\alpha$-glucosidase, $\beta$-glucosidase, $\quad N$-acetyl- $\beta$-glucosaminidase, $\alpha$-mannosidase and $\alpha$-fucosidase. In tests with Biolog GN2 microplates, the strain utilized the following carbon compounds oxidatively: dextrin, D-arabitol, L-arabinose (weakly), D-cellobiose, Dfructose, $\mathrm{D}$-galactose, gentiobiose, $\alpha$-D-glucose, $\alpha$-D-lactose, maltose, D-mannitol, D-mannose, methyl $\beta$-D-glucoside, Dpsicose (weakly), L-rhamnose, D-sorbitol, sucrose, Dtrehalose, turanose, pyruvic acid methyl ester (weakly), succinic acid monomethyl ester, D-galactonic acid lactone, $\alpha$-hydroxybutyric acid, $\alpha$-ketobutyric acid (weakly), $\alpha$ ketoglutaric acid, $\alpha$-ketovaleric acid (weakly), DL-lactic 
acid, succinic acid, succinamic acid (weakly), L-pyroglutamic acid, DL-carnitine (weak), 2,3-butanediol, glycerol, DL- $\alpha$ glycerol phosphate, $\alpha$-D-glucose 1-phosphate and D-glucose 6-phosphate. Strain IMCC $1545^{\mathrm{T}}$ did not utilize the remaining compounds of the GN2 microplate. The strain was resistant to ampicillin, chloramphenicol, gentamicin, kanamycin, penicillin G, rifampicin, streptomycin and vancomycin and susceptible to erythromycin and tetracycline.

The DNA G + C content of strain IMCC $1545^{\mathrm{T}}$ was analysed by using HPLC with a Discovery C18 column $(5 \mu \mathrm{m}$, $15 \mathrm{~cm} \times 4.6 \mathrm{~mm}$; Supelco) (Mesbah et al., 1989). Respiratory quinones were analysed using reverse-phase HPLC by the Korea Culture Center of Micro-organisms (KCCM). Cellular fatty acid methyl esters were prepared from a culture grown on $\mathrm{MA}$ at $30^{\circ} \mathrm{C}$ for 5 days and analysed according to the instructions of the Microbial Identification System (MIDI) by KCCM. The DNA G $+\mathrm{C}$ content of strain IMCC $1545^{\mathrm{T}}$ was $52.1 \pm 0.5 \mathrm{~mol} \%$. The only respiratory quinone detected was menaquinone-7. The major fatty acids in strain $\mathrm{IMCC}_{1545^{\mathrm{T}}}$ were anteiso- $\mathrm{C}_{15: 0}(30.9 \%), \mathrm{C}_{18: 0}$ $(24.7 \%), \mathrm{C}_{16: 0}(7.9 \%)$ and $\mathrm{C}_{17: 0}(7.0 \%)$. Characteristics that differentiate strain IMCC $1545^{\mathrm{T}}$ from other members of subdivision 4 of the phylum 'Verrucomicrobia' are listed in Table 1.

A nearly full-length sequence of the $16 \mathrm{~S}$ rRNA gene (1480 bp) of strain IMCC $1545^{\mathrm{T}}$ was obtained as described previously (Cho et al., 2004) and used for phylogenetic and comparative sequence analyses. Preliminary BLASTN network searches in GenBank showed that the strain belongs to the phylum 'Verrucomicrobia'. According to comparative $16 \mathrm{~S}$ rRNA gene sequence analyses based on the BLASTN searches, the closest named species to strain IMCC $1545^{\mathrm{T}}$ were 'Fucophilus fucoidanolyticus' ( $86.5 \%$ sequence similarity to the proposed type strain SI-1234), Alterococcus agarolyticus $\left(81.8 \%\right.$ similarity to strain $\left.\mathrm{ADT}^{\mathrm{T}}\right)$ and Opitutus terrae $\left(80.3 \%\right.$ similarity to strain $\left.\mathrm{PB} 90-1^{\mathrm{T}}\right)$, and thus the strain was initially considered a novel member of the phylum 'Verrucomicrobia'. To clarify the phylogenetic position of strain IMCC $1545^{\mathrm{T}}$, its $16 \mathrm{~S}$ rRNA gene sequence was aligned carefully using the ARB package (Ludwig et al., 2004) and only 1036 unambiguously aligned nucleotide positions were used for phylogenetic analyses in the ARB package and PAUP* version 4.0 beta 10 (Swofford, 2002). Neighbour-joining, maximum-parsimony and maximumlikelihood phylogenetic trees were generated as described previously (Cho et al., 2004).

In all the phylogenetic trees generated, strain IMCC $1545^{\mathrm{T}}$ formed a tight clade together with the uncultured lake bacterium K2-S-20 within subdivision 4 of the 'Verrucomicrobia' (Fig. 2). This clade was strongly supported by high bootstrap values $(100 \%$ in both neighbour-joining and maximum-parsimony trees) and clearly separated from the nearest clade containing 'Fucophilus fucoidanolyticus', suggesting that strain IMCC $1545^{\mathrm{T}}$ should be placed in a novel genus and species. A large clade containing both 'Fucophilus fucoidanolyticus' and strain IMCC $1545^{\mathrm{T}}$, in spite of low bootstrap support, was clearly

Table 1. Characteristics that differentiate strain IMCC $1545^{\top}$ from other members of subdivision 4 of the 'Verrucomicrobia'

Strains: 1, IMCC1545 ${ }^{\mathrm{T}}$; 2, 'Fucophilus fucoidanolyticus' SI-1234 (Sakai et al., 2003); 3, Alterococcus agarolyticus CCRC 19135 ${ }^{\mathrm{T}}$ (Shieh \& Jean, 1998); 4, Opitutus terrae DSM $11246^{\mathrm{T}}$ (Chin et al., 2001). +, Positive; -, negative; ND, no data available. Cells of all strains are cocci.

\begin{tabular}{|c|c|c|c|c|}
\hline Characteristic & 1 & 2 & 3 & 4 \\
\hline Source & Sea polychaete & Sea cucumber & Hot spring & Rice paddy soil \\
\hline Cell size $(\mu \mathrm{m})$ & $0.6-1.0$ & $1.2-1.6$ & $0.8-0.9$ & $0.4-0.6$ \\
\hline Oxygen demand & Facultatively anaerobic & Aerobic & Facultatively anaerobic & Obligately anaerobic \\
\hline Flagella & - & - & + & + \\
\hline DNA $\mathrm{G}+\mathrm{C}$ content $(\mathrm{mol} \%)$ & $52.1 \pm 0.5$ & 52 & 65.8 & $73.7 \pm 0.3$ \\
\hline Quinone & Menaquinone-7 & Menaquinone-7 & $\mathrm{ND}$ & ND \\
\hline \multicolumn{5}{|c|}{$\mathrm{NaCl}$ concentration for growth $(\%)$} \\
\hline Range & $1.0-10.0$ & $1.0-7.5$ & $1.0-3.5$ & ND \\
\hline Optimum & $2.5-3.0$ & $3.0-3.5$ & $2.0-2.5$ & 3.0 \\
\hline \multicolumn{5}{|l|}{$\mathrm{pH}$ for growth } \\
\hline Range & $5.5-9.5$ & $5.0-12.0$ & $7.0-8.5$ & $5.5-9.0$ \\
\hline Optimum & $7.0-7.5$ & 9.0 & $\mathrm{ND}$ & $7.5-8.0$ \\
\hline \multicolumn{5}{|l|}{ Temperature for growth $\left({ }^{\circ} \mathrm{C}\right)$} \\
\hline Range & $10-40$ & $8-37$ & $40-56$ & $10-37$ \\
\hline Optimum & $30-35$ & $25-30$ & 48 & $\mathrm{ND}$ \\
\hline Oxidase & - & - & + & - \\
\hline Catalase & - & + & + & - \\
\hline Major fatty acids (\%) & $\begin{array}{c}\text { anteiso- } \mathrm{C}_{15: 0}(30.9), \\
\mathrm{C}_{18: 0}(24.7), \mathrm{C}_{16: 0}(7.9)\end{array}$ & ND & $\begin{array}{c}\text { anteiso- } \mathrm{C}_{15: 0}(51.5), \\
\mathrm{C}_{16: 0}(10.6), \mathrm{C}_{14: 0}(6.4)\end{array}$ & ND \\
\hline
\end{tabular}




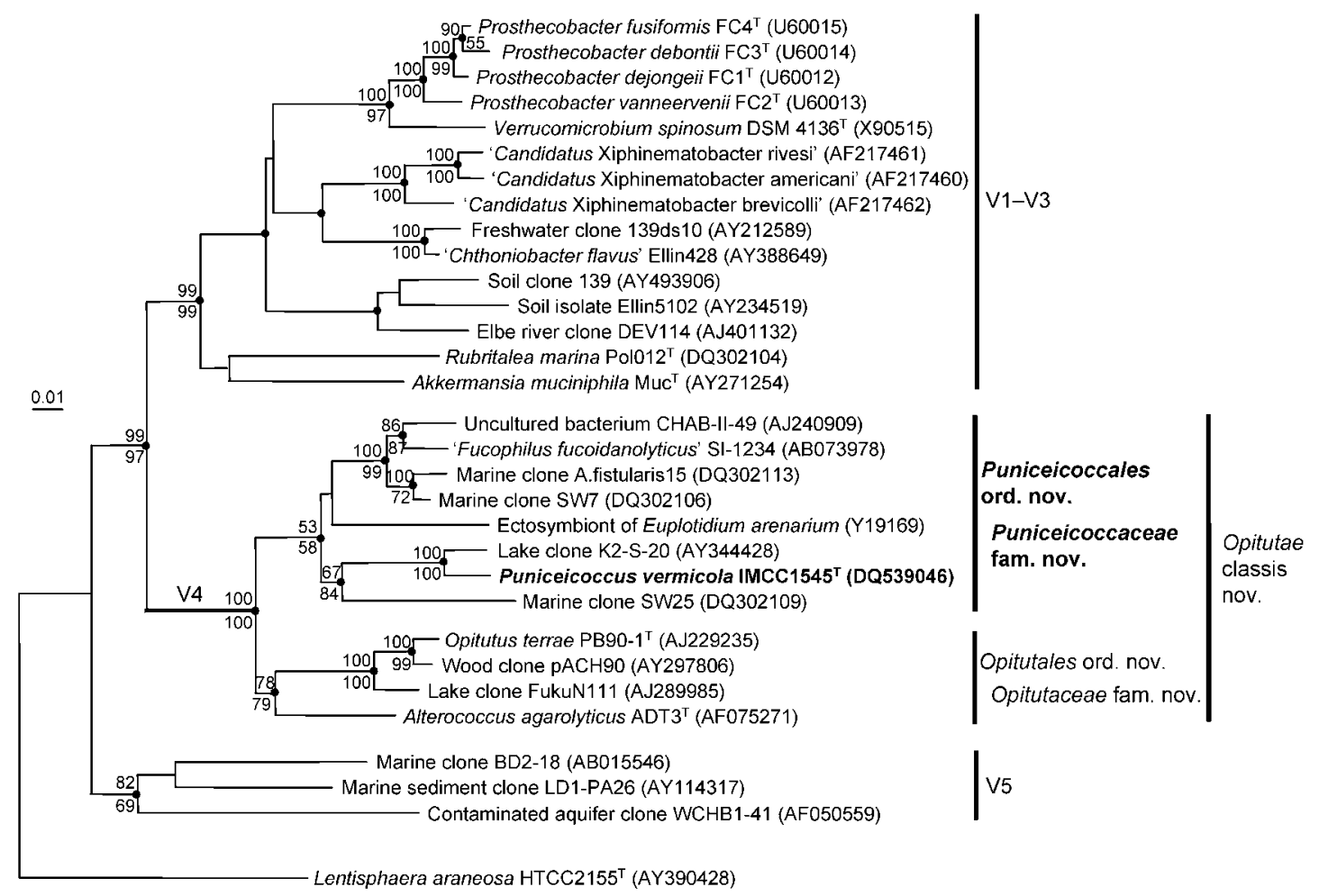

Fig. 2. Neighbour-joining phylogenetic tree based on $16 \mathrm{~S}$ rRNA gene sequences, showing relationships between strain IMCC $1545^{\top}$ and representatives of the phylum 'Verrucomicrobia'. Bootstrap values (above $50 \%$ ) from both neighbour-joining (above nodes) and maximum-parsimony (below nodes) are shown. Filled circles indicate nodes recovered reproducibly by all treeing methods. Other subdivisions of the phylum 'Verrucomicrobia' are shown. Bar, 0.01 substitutions per nucleotide position.

separated from a clade containing Opitutus terrae. Members of the large clade containing strain IMCC $1545^{\mathrm{T}}$ shared only $78.4-82.1 \%$ 16S rRNA gene sequence similarity with members of the adjacent clade containing Opitutus terrae, suggesting that these two clades should be ranked as separate higher taxa, such as novel families or orders. Based on sequence information available from GenBank, the clade containing strain IMCC $1545^{\mathrm{T}}$ consists mainly of uncultured marine and aquatic bacteria and the clade containing Opitutus terrae consists largely of soil bacteria, indicating a habitat-specific distribution of members of the two clades.

In addition to phylogenetic differentiation of strain IMCC $1545^{\mathrm{T}}$ from the other members of subdivision 4 of the 'Verrucomicrobia', phenotypic characteristics clearly differentiated the strain from the most closely related species, 'Fucophilus fucoidanolyticus', Alterococcus agarolyticus and Opitutus terrae (Table 1). The G $+\mathrm{C}$ contents of strain IMCC $1545^{\mathrm{T}}$ and 'Fucophilus fucoidanolyticus' SI-1234 were 13.7-21.8 mol\% lower than those of Alterococcus agarolyticus and Opitutus terrae, showing a distinct genetic difference between the two clades. Recently, the class 'Spartobacteria' and the order 'Chthoniobacterales' were proposed as new names equivalent to subdivision 2 of the phylum 'Verrucomicrobia' (Sangwan et al., 2004). Similar to the above proposal, we formally propose the name Opitutae classis nov. for subdivision 4 of the phylum 'Verrucomicrobia', which contains Opitutales ord. nov. and Puniceicoccales ord. nov. We also propose the names Puniceicoccaceae fam. nov. and Opitutaceae fam. nov. for the clades containing strain IMCC $1545^{\mathrm{T}}$ and the genus Opitutus, respectively, together with a novel genus and species, Puniceicoccus vermicola gen. nov., sp. nov., for strain IMCC $1545^{\mathrm{T}}$.

\section{Description of Opitutae classis nov.}

Opitutae (O.pi.tu'tae. N.L. fem. pl. n. Opitutales type order of the class; -ae ending to denote a class; N.L. fem. pl. n. Opitutae the class of the order Opitutales).

Equivalent to subdivision 4 (Hugenholtz et al., 1998) of the phylum 'Verrucomicrobia' and is defined by phylogenetic analyses based on 16S rRNA gene sequences obtained from four cultured representatives and a wide range of uncultured bacteria retrieved mainly from marine and soil habitats. Gram-negative. The class comprises the order Opitutales and the order Puniceicoccales. The type order is the order Opitutales. 


\section{Description of Opitutales ord. nov.}

Opitutales (O.pi.tu.ta'les. N.L. masc. n. Opitutus type genus of the order; -ales ending to denote an order; N.L. fem. pl. n. Opitutales the order of the genus Opitutus).

Encompasses Gram-negative bacteria retrieved mainly from soil environments, within the class Opitutae of the phylum 'Verrucomicrobia'. The order contains the family Opitutaceae. Delineation of the order is determined primarily by phylogenetic information from 16S rRNA gene sequences. The type genus is the genus Opitutus (Chin et al., 2001).

\section{Description of Puniceicoccales ord. nov.}

Puniceicoccales (Pu.ni.cei.coc.ca'les. N.L. masc. n. Puniceicoccus type genus of the order; -ales ending to denote an order; N.L. fem. pl. n. Puniceicoccales the order of the genus Puniceicoccus).

Encompasses Gram-negative bacteria retrieved mainly from marine environments, within the class Opitutae. The order contains the family Puniceicoccaceae. Delineation of the order is determined primarily by phylogenetic information from $16 \mathrm{~S}$ rRNA gene sequences. The type genus is the genus Puniceicoccus.

\section{Description of Opitutaceae fam. nov.}

Opitutaceae (O.pi.tu.ta'ce.ae. N.L. masc. n. Opitutus type genus of the family; -aceae ending to denote a family; N.L. fem. pl. n. Opitutaceae the family of the genus Opitutus).

Encompasses Gram-negative bacteria retrieved mainly from soil and terrestrial environments, including a hot spring and wood, within the order Opitutales. Currently, the family comprises the genera Opitutus and Alterococcus, together with several uncultured bacteria retrieved mainly from soil environments. Delineation of the family is determined primarily by phylogenetic information from $16 \mathrm{~S}$ rRNA gene sequences. Gram-negative, motile, facultatively or obligately anaerobic cocci. The DNA G $+\mathrm{C}$ content of members of the family is $65-74 \mathrm{~mol} \%$. The type genus is the genus Opitutus (Chin et al., 2001).

\section{Description of Puniceicoccaceae fam. nov.}

Puniceicoccaceae (Pu.ni.cei.coc.ca'ce.ae. N.L. masc. n. Puniceicoccus type genus of the family; -aceae ending to denote a family; N.L. fem. pl. n. Puniceicoccaceae the family of the genus Puniceicoccus).

Encompasses Gram-negative bacteria retrieved mainly from marine and aquatic environments, within the order Puniceicoccales. Currently, the family comprises the genus Puniceicoccus and 'Fucophilus fucoidanolyticus', together with several uncultured marine and lake bacteria. Delineation of the family is determined primarily by phylogenetic information from 16S rRNA gene sequences. The detailed description is the same as for the genus Puniceicoccus. The type genus is the genus Puniceicoccus.

\section{Description of Puniceicoccus gen. nov.}

Puniceicoccus (Pu.ni.cei.coc' cus. L. adj. puniceus pinkish red; N.L. masc. n. coccus from Gr. masc. n. kokkos a berry; N.L. masc. n. Puniceicoccus a pinkish-red-coloured coccus).

Cells are Gram-negative, non-motile, facultatively anaerobic cocci (oval-shaped, 0.6-1.0 $\mu \mathrm{m}$ in diameter). Carotenoid pigments are found. Require $\mathrm{NaCl}$ for growth. The predominant fatty acids are anteiso- $\mathrm{C}_{15: 0}$ and $\mathrm{C}_{18: 0}$. The only respiratory quinone detected is menaquinone- 7 . The DNA G + C content is $52.1 \pm 0.5 \mathrm{~mol} \%$. The type and only species of the genus is Puniceicoccus vermicola.

\section{Description of Puniceicoccus vermicola sp. nov.}

Puniceicoccus vermicola (ver.mi'co.la. L. n. vermis worm; L. suff. -cola from L. n. incola inhabitant; N.L. n. vermicola inhabitant of worms).

In addition to the characteristics reported for the genus, the following are added. Colonies on MA are uniformly circular, smooth, convex, opaque, pale-reddish coloured and $0.3-0.5 \mathrm{~mm}$ in diameter after 5 days of incubation. Colonies are up to $3 \mathrm{~mm}$ in diameter after 3 weeks of incubation. Growth occurs at $8-37^{\circ} \mathrm{C}$, optimally at $25-30{ }^{\circ} \mathrm{C}$, but not at 4 or $42^{\circ} \mathrm{C}$. Growth occurs at $\mathrm{pH} 5-12$ and $1.0-7.5 \% \mathrm{NaCl}$, occurring optimally at $\mathrm{pH} 9.0$ and $3.0-3.5 \% \mathrm{NaCl}$. Oxidase and catalase are negative. Other phenotypic characteristics, including biochemical properties, carbon source utilization, enzyme activities and susceptibility to antibiotics, are given in the text. The fatty acids detected in the type strain are anteiso$\mathrm{C}_{15: 0}(30.9 \%), \mathrm{C}_{18: 0}(24.7 \%), \mathrm{C}_{16: 0}(7.9 \%), \mathrm{C}_{17: 0}(7.0 \%)$, iso- $\mathrm{C}_{14: 0}(5.3 \%), \mathrm{C}_{14: 0}(4.9 \%)$, anteiso- $\mathrm{C}_{17: 0}(3.6 \%)$, $\mathrm{C}_{18: 0} 3-\mathrm{OH}(2.5 \%)$ and $\mathrm{C}_{12: 0} 3-\mathrm{OH}(2.1 \%)$.

The type strain, IMCC $1545^{\mathrm{T}}\left(=\mathrm{KCCM} 42343^{\mathrm{T}}=\mathrm{NBRC}\right.$ $\left.101964^{\mathrm{T}}\right)$, was isolated from the digestive tract of a sea polychaete (Periserrula leucophryna) inhabiting a tidal flat of Donggum island, Korea.

\section{Acknowledgements}

We are grateful to Dr Jae-Sang Hong for his assistance in the collection of marine worms. We would like to thank Dr Jean Euzéby for his recommendations about etymology. This study was supported by the 21C Frontier program of Microbial Genomics and Applications (grant MG05-0102-1-0) from the Ministry of Science and Technology, Republic of Korea. K. L. was supported by a BK21 fellowship from the Ministry of Education and Human Resources Development, Korea.

\section{References}

Chin, K. J., Hahn, D., Hengstmann, U., Liesack, W. \& Janssen, P. H. (1999). Characterization and identification of numerically abundant culturable bacteria from the anoxic bulk soil of rice paddy microcosms. Appl Environ Microbiol 65, 5042-5049.

Chin, K. J., Liesack, W. \& Janssen, P. H. (2001). Opitutus terrae gen. nov., sp. nov., to accommodate novel strains of the division 
'Verrucomicrobia' isolated from rice paddy soil. Int J Syst Evol Microbiol 51, 1965-1968.

Cho, J. C. \& Giovannoni, S. J. (2003). Parvularcula bermudensis gen. nov., sp. nov., a marine bacterium that forms a deep branch in the $\alpha$ Proteobacteria. Int J Syst Evol Microbiol 53, 1031-1036.

Cho, J. C., Vergin, K. L., Morris, R. M. \& Giovannoni, S. J. (2004). Lentisphaera araneosa gen. nov., sp. nov., a transparent exopolymer producing marine bacterium, and the description of a novel bacterial phylum, Lentisphaerae. Environ Microbiol 6, 611-621.

Derrien, M., Vaughan, E. E., Plugge, C. M. \& de Vos, W. M. (2004). Akkermansia muciniphila gen. nov., sp. nov., a human intestinal mucin-degrading bacterium. Int J Syst Evol Microbiol 54, 1469-1476.

Freitag, T. E. \& Prosser, J. I. (2003). Community structure of ammonia-oxidizing bacteria within anoxic marine sediments. Appl Environ Microbiol 69, 1359-1371.

Garrity, G. M., Bell, J. A. \& Lilburn, T. G. (2003). Taxonomic outline of the procaryotes, release 4.0. New York: Springer.

Haukka, K., Heikkinen, E., Kairesalo, T., Karjalainen, H. \& Sivonen, K. (2005). Effect of humic material on the bacterioplankton community composition in boreal lakes and mesocosms. Environ Microbiol 7, 620-630.

Hedlund, B. P., Gosink, J. J. \& Staley, J. T. (1996). Phylogeny of Prosthecobacter, the fusiform caulobacters: members of a recently discovered division of the bacteria. Int J Syst Bacteriol 46, 960-966.

Hedlund, B. P., Gosink, J. J. \& Staley, J. T. (1997). Verrucomicrobia div. nov., a new division of the bacteria containing three new species of Prosthecobacter. Antonie van Leeuwenhoek 72, 29-38.

Hugenholtz, P., Goebel, B. M. \& Pace, N. R. (1998). Impact of culture-independent studies on the emerging phylogenetic view of bacterial diversity. J Bacteriol 180, 4765-4774.

Janssen, P. H., Schuhmann, A., Morschel, E. \& Rainey, F. A. (1997). Novel anaerobic ultramicrobacteria belonging to the Verrucomicrobiales lineage of bacterial descent isolated by dilution culture from anoxic rice paddy soil. Appl Environ Microbiol 63, 1382-1388.

Ludwig. W., Strunk, O., Westram, R., Richter, L., Meier, H., Yadhukumar, Buchner, A., Lai, T., Steppi, S. \& other authors (2004). ARB: a software environment for sequence data. Nucleic Acids Res 32, 1363-1371.

Mesbah, M., Premachandran, U. \& Whitman, W. B. (1989). Precise measurement of the $\mathrm{G}+\mathrm{C}$ content of deoxyribonucleic acid by highperformance liquid chromatography. Int J Syst Bacteriol 39, 159-167.

O'Farrell, K. A. \& Janssen, P. H. (1999). Detection of Verrucomicrobia in a pasture soil by PCR-mediated amplification of $16 \mathrm{~S}$ rRNA genes. Appl Environ Microbiol 65, 4280-4284.

Sakai, T., Ishizuka, K. \& Kato, I. (2003). Isolation and characterization of a fucoidan-degrading marine bacterium. Mar Biotechnol 5, 409-416.

Sangwan, P., Chen, X., Hugenholtz, P. \& Janssen, P. H. (2004). Chthoniobacter flavus gen. nov., sp. nov., the first pure-culture representative of subdivision two, Spartobacteria classis nov., of the phylum Verrucomicrobia. Appl Environ Microbiol 70, 5875-5881.

Schlesner, H. (1987). Verrucomicrobium spinosum gen. nov., sp. nov.; a fimbriated prosthecate bacterium. Syst Appl Microbiol 10, 54-56.

Shieh, W. Y. \& Jean, W. D. (1998). Alterococcus agarolyticus, gen. nov., sp. nov., a halophilic thermophilic bacterium capable of agar degradation. Can J Microbiol 44, 637-645.

Smibert, R. M. \& Krieg, N. R. (1994). Phenotypic Characterization. Washington, DC: American Society for Microbiology.

Swofford, D. (2002). PAUP* Phylogenetic Analysis Using Parsimony (and other methods). Sunderland, MA: Sinauer Associates.

Ward-Rainey, N., Rainey, F. A., Schlesner, H. \& Stackebrandt, E. (1995). Assignment of hitherto unidentified 16S rDNA species to a main line of descent within the domain Bacteria. Microbiology 141, 3247-3250. 